\title{
Enhanced Cysteinyl-Leukotriene Type 1 Receptor Expression in T Cells from House Dust Mite-Allergic Individuals following Stimulation with Der $p$
}

\author{
Maryse Thivierge, Sylvie Turcotte, Marek Rola-Pleszczynski, and Jana Stankova
}

Division of Immunology and Allergy, Department of Pediatrics, Faculty of Medicine and Health Sciences, Université de Sherbrooke, Sherbrooke, QC, Canada J1H 5N4

Correspondence should be addressed to Jana Stankova; jana.stankova@usherbrooke.ca

Received 20 November 2014; Revised 20 February 2015; Accepted 4 March 2015

Academic Editor: Steven E. Finkelstein

Copyright (C) 2015 Maryse Thivierge et al. This is an open access article distributed under the Creative Commons Attribution License, which permits unrestricted use, distribution, and reproduction in any medium, provided the original work is properly cited.

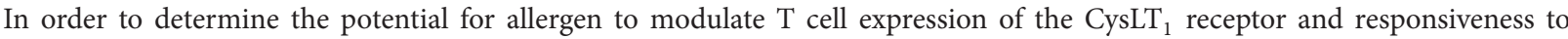
leukotrienes, peripheral blood mononuclear cells from house dust mite-allergic or nonallergic individuals were incubated with $D$. pteronyssinus allergen (Der $\mathrm{p}$ ). Baseline CysLT ${ }_{1}$ expression was similar in both groups of donors, but Der p significantly enhanced CysLT $_{1}$ expression in $\mathrm{CD}^{+}$and $\mathrm{CD}^{+} \mathrm{T}$ cells of only allergic individuals and induced enhanced responsiveness of $\mathrm{CD} 4^{+} \mathrm{T}$ cells to $\mathrm{LTD}_{4}$ in terms of calcium mobilisation. This effect was prevented by the CysLT 1 antagonist MK571. Der p also induced IL- 4 and IL10 production, and neutralizing antibody to IL- 4 prevented both the enhanced CysLT ${ }_{1}$ expression and the enhanced responsiveness of T cells to $\mathrm{LTD}_{4}$ induced by Der $\mathrm{p}$. In allergic individuals, Der $\mathrm{p}$ also induced $\mathrm{T}$ cell proliferation and a Th2-biased phenotype. Our data suggest that, in allergen-sensitized individuals, exposure to allergen can enhance T cell expression of CysLT $\mathrm{T}_{1}$ receptors through a mechanism involving IL-4 production. This, in turn, would induce CD $4^{+} \mathrm{T}$ cell responsiveness to cysteinyl-leukotrienes and Th2 cell activation.

\section{Introduction}

Cysteinyl-leukotrienes (cysLTs), leukotriene $\mathrm{C}_{4}, \mathrm{LTD}_{4}$, and $\mathrm{LTE}_{4}$, are lipid mediators of inflammation well known to be involved in the pathogenesis of asthma and the resulting pulmonary inflammation [1]. They are mainly produced by eosinophils, mast cells, basophils, monocytes, macrophages, and dendritic cells (DC) from arachidonic acid through the 5-lipoxygenase pathway [2]. CysLTs act on at least three G-protein-coupled receptors designated $\mathrm{CysLT}_{1}, \mathrm{CysLT}_{2}$, and GPR99 [3-6]. CysLT 1 , recognized as the high-affinity receptor for $\mathrm{LTD}_{4}$, is expressed mainly in peripheral blood leukocytes, including eosinophils, monocytes, neutrophils, basophils, DC, B lymphocytes, and T cells, as well as in mast cells, interstitial lung macrophages, and bronchial smooth muscle cells [7-13]. CysLT 2 binds LTC $_{4}$ and LTD $_{4}$ with similar affinity and is widely expressed in many tissues, including heart, adrenal, lung, spleen, endothelium, and peripheral blood leukocytes, and less strongly in the brain [5]. In contrast, the more recently characterized GPR99 is mainly activated by $\mathrm{LTE}_{4}$ and is widely expressed in nonhematopoietic tissues [6]. The expression of CysLT $\mathrm{C}_{1}$ and $\mathrm{CysLT}_{2}$ receptors can be modulated in the presence of cytokines such as IL-4, IL-5, IL-13, IFN- $\gamma$, or TGF- $\beta$, at both the mRNA and protein levels in different cell populations [12, 14-17]. CysLTs have been found to promote cytokine and chemokine expression in various cellular models and IgE production by human B cells $[15,18-21]$.

House dust mites (HDM) are a major source of allergens that contribute to the rising incidence of allergic asthma [22]. Asthma and allergic rhinitis are inflammatory diseases characterized by the influx of multiple cell types to affected tissue sites and the increased expression of both CysLT $_{1}$ and $\mathrm{CysLT}_{2}$ as compared with circulating cells or those present in noninflamed tissue $[7,23]$. These diseases are associated with a complex cytokine milieu described mainly as Th2 in 
nature (IL-4, IL-13, and IL-9), but including Th1 cytokines (IFN- $\gamma$ ) as well. Exposure to mite allergens induces cysLT production from a number of constitutive and inflammatory cells in asthmatic airways, including epithelial cells, mast cells, and eosinophils [24]. In atopic patients, DC pulsed with HDM allergens produced a significant increase in cysLT production and showed a Th2-favoring phenotype with a Th2-skewed cytokine production from autologous $\mathrm{CD}_{4}^{+} \mathrm{T}$ cells [25]. In mice, HDM allergen was shown to elicit both cysLT generation and $\mathrm{CysLT}_{1}$ receptor-mediated priming of dendritic cell function in an autocrine fashion to promote allergic inflammation [26]. Different studies have shown that DC from allergic patients exposed to the allergen Dermatophagoides pteronyssinus (Der p) were able to promote Th2 responses through an overproduction of IL-10 and to favor an increase in IL-4 production by autologous T cells $[27,28]$. The proteolytic activity of Der $p$ has been shown to bias human $\mathrm{T}$ cells towards a helper type 2 cytokine profile by inducing them to produce more IL- 4 and less IFN- $\gamma$ [29]. Such findings suggest that exposure to an allergen induces $\mathrm{T}$ helper cell polarization to Th2 in the sensitized host.

Whereas resting $\mathrm{T}$ lymphocytes were found to display low cell surface expression of CysLT $\mathrm{C}_{1}$ and $\mathrm{CysLT}_{2}, \mathrm{~T}$ cell activation through the $\mathrm{T}$ cell receptor (TcR) was shown to induce an important rise in the percentages of CysLT ${ }_{1}$ and CysLT $_{2}$ positive cells [30]. In addition, CysLT $_{1}$ upregulation after TcR activation of mouse $\mathrm{T}$ cells was associated with enhanced $\mathrm{LTD}_{4}$-elicited calcium flux and migration toward $\operatorname{LTD}_{4}[13]$.

In the present study, we investigated the effects of Der $\mathrm{p}$ on CysLT receptor expression on human $\mathrm{T}$ cell populations. In particular, we incubated PBMC from HDM-allergic or HDM-nonallergic individuals with Der $\mathrm{p}$ allergen and analyzed the expression and functional activity of CysLT and CysLT 2 on $\mathrm{T}$ cell subsets. We hypothesized that Der $\mathrm{p}$ could differentially modulate these receptors according to the allergic status of the donors.

\section{Materials and Methods}

2.1. Reagents. The HDM allergen Dermatophagoides pteronyssinus, Der p, was obtained from Omega Laboratories (Pointe-Claire, QC, Canada). Human recombinant IL-4 and IL-10 were purchased from Peprotech (Rocky Hill, NJ, USA). $\mathrm{LTD}_{4}$ and rabbit polyclonal anti-human CysLT ${ }_{1}$ and $\mathrm{CysLT}_{2}$ $\mathrm{Ab}$ were obtained from Cayman Chemical (Ann Arbor, $\mathrm{MI}$ ). The CysLT ${ }_{1}$ antagonist montelukast was a generous gift from Merck-Frosst (Point-Claire, Québec, Canada) whereas MK-571 was obtained from Biomol Research Laboratories (Plymouth Meeting, PA). Rabbit IgG isotype control was purchased from Southern Biotechnology Associates (Birmingham, AL); mouse IgG isotype control (G155-178), mouse anti-CD4 PE-CY5, mouse anti-CD8 PE, and anti-CD3 APC were purchased from BD Pharmingen (Mississauga, Ontario, Canada). Rabbit polyclonal anti-human IL-4 and IL-10 Ab were purchased from R\&D Cedarlane.
2.2. Cell Culture. Venous blood was collected from donors sensitive or not sensitive to the HDM allergen Der p by history and skin tests or specific serum IgE. All donors were recruited following consent to a protocol (98-20-R16) approved by the Université de Sherbrooke Ethics Review Board. Peripheral blood mononuclear cells (PBMC) were isolated through Ficoll-Hypaque density centrifugation. PBMC were used for some experiments or depleted of their monocyte population by adherence. $\mathrm{CD} 4^{+}$and $\mathrm{CD} 8^{+} \mathrm{T}$ cells were purified from whole blood lymphocytes by depletion of contaminating cells using the "human $\mathrm{CD}^{+} \mathrm{T}$ or $\mathrm{CD}^{+} \mathrm{T}$ cell enrichment kit, negative selection" (Stemcell Technologies, Vancouver, BC, Canada) following the manufacturer's instructions. Purity was greater than $98 \%$. The cells were washed and resuspended in complete RPMI 1640 medium supplemented with $5 \%$ FBS and maintained at $37^{\circ} \mathrm{C}$ in $5 \% \mathrm{CO}_{2}$. Cells were stimulated with the cytokines IL-4 ( $40 \mathrm{ng} / \mathrm{mL}$ ) or IL-10 ( $20 \mathrm{ng} / \mathrm{mL}$ ) for $48 \mathrm{~h}$ before RNA was harvested or $72 \mathrm{~h}$ for studies involving protein expression or calcium flux assay. In some experiments, PBMC were stimulated with vehicle control (glycerin) or Der p $(200 \mathrm{AU} / \mathrm{mL})$ for 48 to $72 \mathrm{~h}$ before supernatant collection and $\mathrm{CD} 4^{+}$and $\mathrm{CD} 8^{+}$ $\mathrm{T}$ cell subpopulations analysis for their CysLT1R expression or responsiveness. In selected experiments, total lymphocytes were stimulated with IL-4 and IL-10 or incubated on antiCD3-precoated petri dishes.

\subsection{Flow-Cytometric Measurement of Expression of CysLT} Receptors. Following treatment, PBMC were washed, resuspended with PBS, fixed with $2 \%$ paraformaldehyde for $15 \mathrm{~min}$ at room temperature, and permeabilized with $0.1 \%$ saponin for an additional $20 \mathrm{~min}$ at room temperature. After blocking with human IgG $\left(20 \mu \mathrm{g} / 1 \times 10^{6}\right.$ cells) for $15 \mathrm{~min}$ at room temperature, cells were resuspended with PBS-2\% FBS and labeled for $30 \mathrm{~min}$ with rabbit polyclonal anti-human $\mathrm{CysLT}_{1}$ or CysLT 2 Abs or with rabbit IgG isotype control Ab. Cells were then washed with PBS and incubated for $30 \mathrm{~min}$ with FITC-conjugated goat anti-rabbit IgG. Cells were also labeled with mouse anti-human CD4 PE-CY5, anti-CD8 PE, and anti-CD3APC (BD Pharmingen). Finally, cells were acquired and analyzed on a FACSCalibur flow cytometer using the CellQuest Pro software.

2.4. Assessment of T Cell Proliferation. PBMC were washed twice with PBS, incubated in protein-free PBS, and labeled for $5 \mathrm{~min}$ at room temperature with $5 \mu \mathrm{M}$ of CSFE (5carboxy fluorescein diacetate succinimidyl ester) (Molecular Probes, Eugene, OR). Cells were washed three times with PBS containing 5\% FBS, resuspended in RPMI 5\% FBS, and incubated with Der p (200 AU/mL) or its vehicle (glycerin) for up to 8 days. At different periods of time, cells were collected and labelled with anti-CD4 PE-Cy5, anti-CD8 PerCP-Cy5, and anti-CD3 APC (BD Pharmingen). Fractions of stained cells were acquired and analyzed on a FACSCalibur flow cytometer to calculate the percentage of $\mathrm{CD}^{+} \mathrm{T}$ cells undergoing division. A CFSE profile was generated using FlowJo v7/8 (Tree Star Inc., Ashland, OR, USA). 
2.5. Th1 and Th2 Marker Analysis. PBMC were incubated in RPMI 5\% FBS with Der p (200 AU/mL) or its vehicle (glycerin) for up to 11 days. On day 6 , one volume of fresh medium supplemented with the stimuli was added to the cells. On day 11, cells were harvested and incubated for 30 minutes at $4^{\circ} \mathrm{C}$ with fluorochrome-conjugated monoclonal antibodies: CD184 PE (CXCR4 Ab), CD183 Alexa 488 (CXCR3 Ab), and CD294 Alexa 647 (CRTH2 Ab) (BD Pharmingen, San Diego, CA, USA) antibodies known to recognize Th cell surface markers associated with Th0, Th1, and Th2, respectively [31, 32]. Labeled cells were resuspended in PBS and fluorescence was analyzed on a FACSCalibur cytometer equipped with CellQuest Pro software.

2.6. RNA Isolation and Real-Time Quantitative PCR. Cellular RNA was obtained using Trizol reagent (Invitrogen, Burlington, ON, Canada) according to the manufacturer's instructions. After total RNA purification with RNeasy kit (Qiagen, Mississauga, ON, Canada), $1.0 \mu \mathrm{g}$ of RNA was converted to cDNA with oligo-dT (Fermentas, Burlington, $\mathrm{ON}$, Canada) and reverse transcriptase (M-MLV; Promega, Madison, WI, USA) in a volume of $20 \mu \mathrm{L}$. CysLT 1, CysLT $_{2}$, and GAPDH expression was measured using real-time quantitative PCR performed on a Rotor-Gene 3000 (Corbett Research, Kirkland, QC, Canada). The following oligonucleotide primer sets were obtained from Integrated DNA Technologies (Coralville, IA, USA): human $\mathrm{CysLT}_{1}$ : forward, $5^{\prime}$-CCTCAGCACCTATGCTTTGT- $3^{\prime}$ and reverse, $5^{\prime}$-ATTGTCTTGTGGGGGCTCAA-3' (amplifying a 249-bp fragment); human CysLT 2 : forward, $5^{\prime}$-AGACTGCATAAAGCTTTGGTTATC- $3^{\prime}$ and reverse, $5^{\prime}$-ATACTCTTGTTTCCTTTCTCAACC-3' (amplifying a 196-bp fragment); and human GAPDH: forward, 5-GATGACATCAAGAAGGTGGTGAA-3 and reverse, 5-GTCTTACTCCTTGGAGGCCATGT-3 (amplifying a 246-bp fragment).

Each sample for real-time PCR consisted of $1 \mu \mathrm{L} c \mathrm{cNA}$, $2.5 \mathrm{mM} \mathrm{MgCl}_{2}, 100 \mu \mathrm{M} \mathrm{dNTP}, 1 \mu \mathrm{M}$ of primers, $2.5 \mu \mathrm{L}$ of 10x PCR buffer, 0.5 unit of Taq polymerase (New England Biolabs, Pickering, Ontario, Canada), and $0.8 \mu \mathrm{L}$ of SYBR Green (Molecular Probe, Eugene, OR; 1/1000 stock dilution) in a reaction volume of $25 \mu \mathrm{L}$. The cycling program consisted of an initial denaturation at $95^{\circ} \mathrm{C}$ for $5 \mathrm{~min}$ and 40 cycles of amplification conditions as follows: $95^{\circ} \mathrm{C}(30 \mathrm{sec}), 60^{\circ} \mathrm{C}$ $(30 \mathrm{sec})$, and $72^{\circ} \mathrm{C}(30 \mathrm{sec})$, with the fluorescence read at the end of each cycle. Comparison of the expression of each gene between its control and stimulated states was determined with the delta-delta $(\Delta \Delta) \mathrm{Ct}$, according to the following formula: $\Delta \Delta \mathrm{Ct}=[(\mathrm{Ct}$ G.O.I.Ctl $-\mathrm{Ct}$ HK.G.Ctl $)-(\mathrm{Ct}$ G.O.I.STIM. - Ct HK.G.STIM.)]. Results were then transformed into fold variation measurements: fold increase $=$ $2^{\Delta \Delta \mathrm{Ct}}$.

2.7. Measurement of Intracellular Calcium. Intracellular free calcium was measured on a FACSCalibur (Becton-Dickinson). T cells at $4 \times 10^{6} / \mathrm{mL}$ were incubated for $30 \mathrm{~min}$ at room temperature in $1 \mathrm{~mL}$ HBSS containing $0.35 \mathrm{~g} / \mathrm{L} \mathrm{NaHCO}_{3}$ and $10 \mathrm{mM}$ HEPES pH 7.0, with $3 \mu \mathrm{M}$ fluo-4AM (Molecular Probes). The dye-loaded cells were then washed and resuspended in HBSS containing $2 \mathrm{mM} \mathrm{CaCl}_{2}$ and baseline fluorescence was measured at $0 \mathrm{~s}$. Fluorescence released after $\mathrm{LTD}_{4}$ stimulation $(100 \mathrm{nM})$ was recorded every $15 \mathrm{~s}$ for $2 \mathrm{~min}$. Intracellular free calcium was measured on a FACSCalibur flow cytometer (Becton-Dickinson) using the CellQuestPro software (BD Bioscience) and analyzed with FlowJo v7/8 (Tree Star Inc., Ashland, OR, USA).

2.8. Cytokine Detection. Cytokines were measured with commercial ELISA (BD Biosciences, San Diego, CA, USA) according to the manufacturer's instructions. Lower limits of detection for these ELISA were $2 \mathrm{pg} / \mathrm{mL}$ for both IL- 4 and IL10.

2.9. Statistical Analysis. Statistical significance was calculated using Prism 5 software (GraphPad Software, San Diego, CA). For analysis of differences between experimental groups, Student's $t$-test and one-way or two-way ANOVA with Bonferroni posttest were used, as appropriate. Values of $P \leq 0.05$ were considered statistically significant.

\section{Results}

3.1. CysLT $T_{1}$ Expression on T Cells Is Enhanced by Der p. In a first series of experiments, we compared the effect of Der p on CysLT $_{1}$ and CysLT ${ }_{2}$ expression in T cells from HDM-allergic and HDM-nonallergic individuals. PBMC from individuals of either group were exposed to either glycerin vehicle or Der p $(200 \mathrm{AU} / \mathrm{mL})$ for $48 \mathrm{~h}$ before purification of $\mathrm{CD}^{+}$ and $\mathrm{CD}^{+} \mathrm{T}$ cells. RNA from these purified cells was then isolated and $\mathrm{CysLT}_{1}$ and $\mathrm{CysLT}_{2}$ mRNA expression was analyzed by real-time PCR. As illustrated in Figures 1(a) and 1(b), $\mathrm{CD}^{+}$and $\mathrm{CD} 8^{+} \mathrm{T}$ cells from HDM-allergic subjects showed a significantly increased $\mathrm{CysLT}_{1}$, but not CysLT 2 , mRNA expression upon stimulation with Der p. In contrast, Der $\mathrm{p}$ failed to modulate either CysLT 1 or $\mathrm{CysLT}_{2}$ mRNA expression in cells from nonallergic individuals.

In additional experiments, PBMC were also exposed for $72 \mathrm{~h}$ to either Der $\mathrm{p}$ or glycerin vehicle before cytometry analysis of $\mathrm{CysLT}_{1}$ or $\mathrm{CysLT}_{2}$ protein expression on $\mathrm{CD}^{+}$ and $\mathrm{CD}^{+} \mathrm{T}$ cell subpopulations. Whereas both receptors are widely expressed on peripheral blood leukocytes, they are not highly expressed on circulating $\mathrm{T}$ cells, with less than $10 \%$ of cells expressing CysLT ${ }_{1}$ or $\mathrm{CysLT}_{2}[5,7,23]$. Cell surface CysLT ${ }_{1}$ and Cys $\mathrm{CT}_{2}$ expression was constitutively present on both subpopulations of T cells with basal levels of $\mathrm{CysLT}_{1}$ and $\mathrm{CysLT}_{2}$ expression ranging from $2.5 \%$ to $10 \%$ of cells and not significantly different between healthy donors and HDM-sensitive subjects (data not illustrated). However, stimulation with Der p significantly increased CysLT $_{1}$ expression (Figure 1(c)), without affecting CysLT 2 expression (not shown), in both $\mathrm{T}$ cell subpopulations from HDM-allergic donors. In contrast, as observed at the mRNA level, $\mathrm{CysLT}_{1}$ expression on $\mathrm{T}$ cells from nonallergic donors was not modulated by Der p exposure.

3.2. Proliferation and Polarization of $T$ Cells. $\mathrm{T}$ cell polarization toward a Th1 or a Th2 profile is dependent on 
HDMA

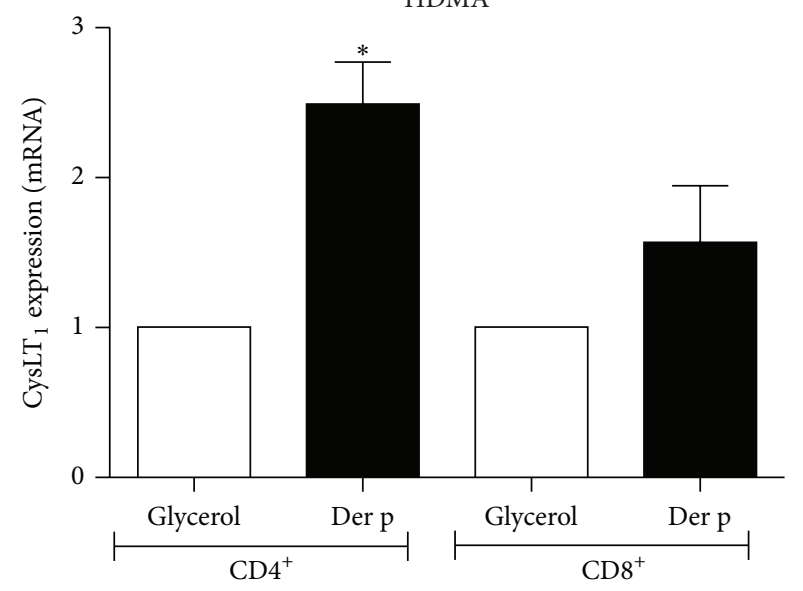

(a)
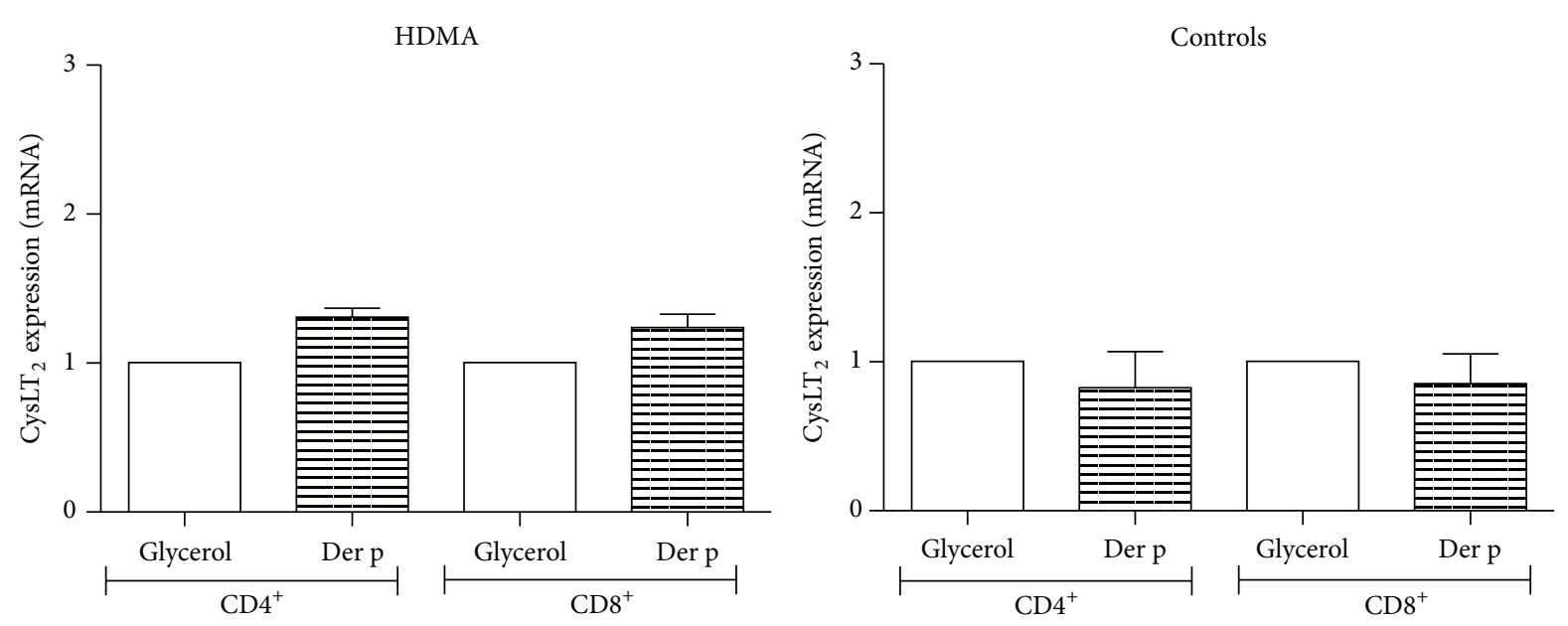

(b)

HDMA
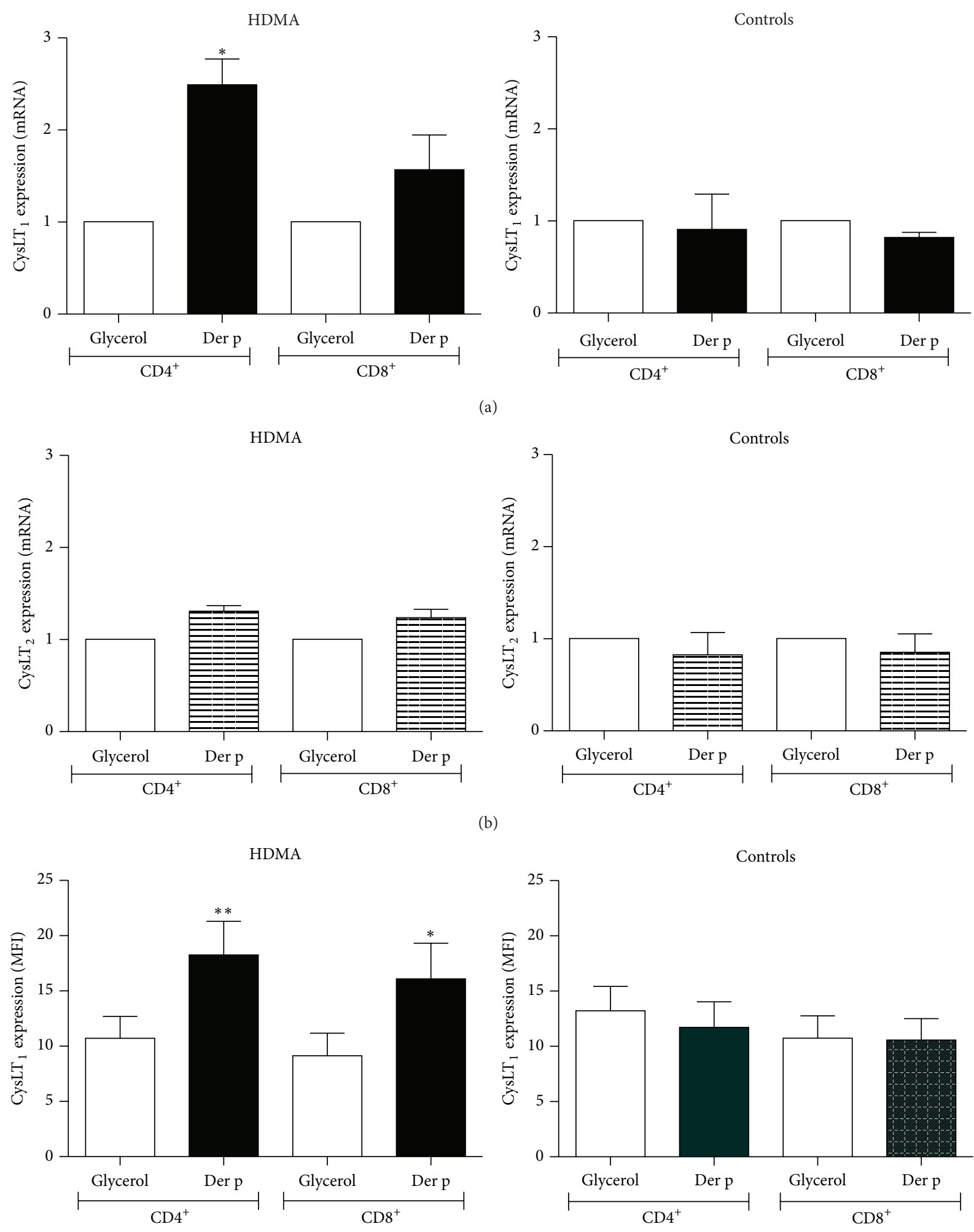

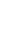

(1)

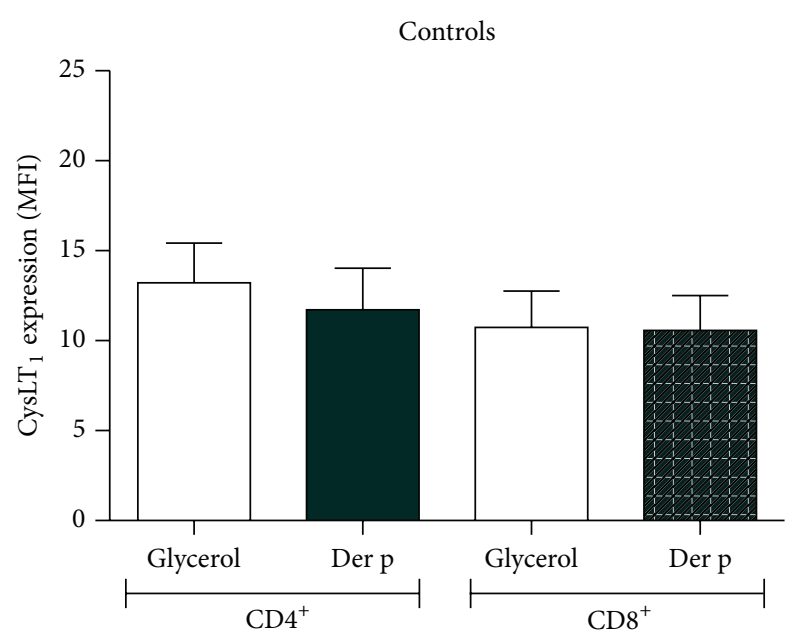

(c)

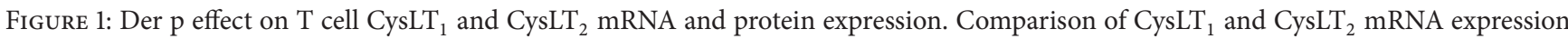
in $\mathrm{CD}^{+}$and $\mathrm{CD}^{+} \mathrm{T}$ cells from healthy controls and HDM-allergic (HDMA) patients following stimulation with the Der $\mathrm{p}$ allergen (200 AU/mL). PBMC from healthy control and HDMA subjects were cultured for $48 \mathrm{~h}$ (qPCR) or $72 \mathrm{~h}$ (FACS) in the presence of glycerol vehicle or Der $\mathrm{p}$ before $\mathrm{CD}^{+}$and $\mathrm{CD}^{+} \mathrm{T}$ cells were purified and collected for analysis. $\mathrm{CysLT}_{1}$ (a) and CysLT 2 (b) mRNA expression was measured by real-time quantitative PCR analysis. Data are presented as fold $(\Delta \Delta \mathrm{Ct})$ increases over GAPDH mRNA $( \pm \mathrm{SEM}) .{ }^{*} P<0.05$ and ${ }^{* *} P<0.01$, relative to vehicle glycerol; $n=6$ for controls; $n=10$ for HDMA. Cell surface expression of CysLT (c) $_{1}$ receptor was evaluated using rabbit polyclonal anti-CysLT 1 receptor $\mathrm{Ab}$, followed by labeling with FITC-conjugated goat anti-rabbit IgG. Cells were further incubated with anti-CD4 PE-Cy5 and anti-CD8 PE Ab before analysis on a FACSCalibur flow cytometer. Data are expressed as geometric mean ( \pm SEM) fluorescence intensity (MFI). ${ }^{*} P<0.05 ; n=6$ for controls; $n=10$ for HDMA. 
the cytokines present when the interaction of APC with T cells occurs. Allergic diseases are characterized by a predominant Th2 profile. We thus examined whether Der p could induce $\mathrm{T}$ cells from HDM-allergic individuals to proliferate and to develop a Th2 phenotype. T cell proliferation was measured by CFSE dye dilution. As depicted in Figure 2(a), the proliferative response of CFSE-labeled $\mathrm{CD} 4^{+} \mathrm{T}$ cells from HDM-allergic patients was enhanced following Der p stimulation of PBMC. In contrast, we observed no proliferation of $\mathrm{CD} 4^{+} \mathrm{T}$ cells from nonallergic donors.

We next examined the expression of markers that have been associated with either Th1 or Th2 cell types on $\mathrm{CD} 4^{+}$ and $\mathrm{CD}^{+}$cells from allergic patients and healthy individuals. CXCR3 (CD183) has been proposed as a marker associated with Th1 responses [31] and the $\mathrm{PGD}_{2}$ receptor CD294, also referred to as chemoattractant receptor expressed on Th2 cells (CRTH2), has recently emerged as a marker of Th2cell functions [32]. In the present study we investigated the effect of Der $\mathrm{p}$ on the expression of these two markers on $\mathrm{CD}^{+}{ }^{+} \mathrm{T}$ cells from HDM-sensitive and HDM-nonallergic donors. Using flow cytometry analysis, the expressions of CD183 (Th1 marker) and CD294 (Th2 marker) were assessed in $\mathrm{CD}^{+} \mathrm{T}$ cells after incubation of PBMC in the presence of Der p. As illustrated in Figures 2(b)-2(e), Der p treatment significantly reduced the proportion of CD183 positive cells and increased the proportion of CD294 positive cells in HDM-allergic donors, with a ratio of Th2/Th1 cell markers greater than 1.5. Nonallergic donors showed an unchanged ratio of approximately 1.0.

3.3. Role of IL-4 in Der p-Enhanced CysLT $T_{1}$ Expression on $T$ Cells. We evaluated the effect of Der $\mathrm{p}$ on the production of IL- 4 and IL-10 by PBMC from allergic patients and healthy donors. Cell-free supernatants were collected from PBMC incubated for $48 \mathrm{~h}$ with Der $\mathrm{p}$ and analyzed for cytokine production by ELISA. PBMC from HDM-sensitive patients produced significantly higher amounts of the cytokines IL-10 and IL-4 (Figures 3(a) and 3(b)). In contrast, when PBMC from HDM-nonallergic donors were incubated with Der $\mathrm{p}$, the induction of IL-4 and IL-10 production was only modest and statistically nonsignificant. Basal IL-4 and IL-10 production by unstimulated cells was similar in PBMC from allergic and healthy subjects.

We next tested the effect of IL-4 and IL-10 on CysLT 1 expression in $\mathrm{T}$ cells. $\mathrm{CD} 4{ }^{+} \mathrm{T}$ cells from normal donors were stimulated with anti-CD3 $\mathrm{Ab}$ or with the cytokines IL-4 and IL-10 for $72 \mathrm{~h}$. Stimulation of both $\mathrm{CD}^{+}$and $\mathrm{CD} 8^{+}$ cells with either IL-4 or IL-10 resulted in enhanced CysLT 1 expression (Figure 3(c)). Similarly, T cell activation through the $\mathrm{T}$ cell receptor/CD3 complex was found to enhance CysLT ${ }_{1}$ expression in T cells (Figure 3(d)).

We next investigated whether the Der p-induced effect on CysLT $_{1}$ expression was dependent on IL-4 and/or IL-10. To this aim, we added anti-IL- 4 or anti-IL-10 neutralizing Ab to the PBMC from allergic donors before stimulation with Der $\mathrm{p}$ and measured CysLT ${ }_{1}$ expression in $\mathrm{CD}_{4}^{+}$and $\mathrm{CD}^{+} \mathrm{T}$ cells after $48 \mathrm{~h}$. As shown in Figure 3(e), addition of anti-IL-4 Ab significantly abrogated the effect of Der $\mathrm{p}$ on CysLT ${ }_{1}$ mRNA expression of both $\mathrm{CD} 4^{+}$and $\mathrm{CD} 8^{+}$cells, whereas the use of anti-IL-10 only partially reversed this effect. A similar effect of these anti-cytokine Abs was also observed at the CysLT 1 protein level (data not illustrated).

3.4. Functional Analysis of Increased Leukotriene Receptor Expression. Having demonstrated that Der p and IL-4 can increase $\mathrm{CysLT}_{1}$ expression on $\mathrm{T}$ cells, we investigated whether the increased levels of expression led to enhanced $\mathrm{LTD}_{4}$ signaling in $\mathrm{T}$ cells. The biological activity of the receptors on $\mathrm{T}$ cells was assessed by measuring intracellular calcium flux in response to $\mathrm{LTD}_{4}$, the physiological ligand of $\mathrm{CysLT}_{1}$. PBMC from allergic and nonallergic subjects were exposed for $72 \mathrm{~h}$ to Der $\mathrm{p}$, after which cells were analyzed in a calcium mobilization assay. As shown in Figures 4(a) and 4(b), stimulation of $\mathrm{CD} 4^{+} \mathrm{T}$ cells from HDM-allergic donors with $\mathrm{LTD}_{4}$ induced a discrete response in calcium mobilization, and pretreatment with Der p resulted in an enhanced response to the ligand. The $\mathrm{Ca}^{2+}$ mobilization observed in $\mathrm{CD}^{+}{ }^{+} \mathrm{T}$ cells was prevented by MK571, a specific CysLT ${ }_{1}$ antagonist. Furthermore, the addition of neutralizing Abs to IL-4 abrogated the enhanced calcium response to $\mathrm{LTD}_{4}$ of Der p-treated $\mathrm{CD}^{+}{ }^{+} \mathrm{T}$ cells from HDM-allergic individuals. In contrast, neutralizing Abs to IL-10 failed to affect the response. Whereas $\mathrm{CD}^{+} \mathrm{T}$ cells from nonallergic donors responded to $\mathrm{LTD}_{4}$ stimulation similarly to $\mathrm{HDM}$-allergic donors in terms of calcium mobilization, they maintained the same basal responsiveness whether or not they had been preincubated with Der $\mathrm{p}$ (data not illustrated).

\section{Discussion}

The present study demonstrated that the Der $\mathrm{p}$ allergen induced an increased expression of CysLT ${ }_{1}$ receptor in $\mathrm{CD}_{4}^{+}$ and $\mathrm{CD}^{+} \mathrm{T}$ cells from HDM-allergic subjects, whereas Der $\mathrm{p}$ had no significant effects on T cells from non-HDMallergic individuals. This upregulation of $\mathrm{CysLT}_{1}$ expression by Der $p$ induced an enhanced responsiveness of $\mathrm{T}$ cells to $\mathrm{LTD}_{4}$. Previous studies reported that HDM allergens could modulate cysLT production or CysLT receptor expression in mouse and human dendritic cells (DC). Hence, in murine bone marrow-derived DC, Machida et al. [26] reported that D. farinae allergen significantly increased CysLT 1 receptor, 5-LO, FLAP, and $\mathrm{LTC}_{4} \mathrm{~S}$ mRNA and cysLT production. Saeki et al. [25] reported that human monocyte-derived DC from D. farinae allergen-sensitized subjects expressed CysLT receptor, 5-LO, FLAP, and $\mathrm{LTC}_{4} \mathrm{~S}$ mRNA and $D$. farinae pulsing significantly enhanced their cysLT production. A link between HDM allergens and cysLT production also has been reported in other cell populations of asthmatic airways, including epithelial cells, mast cells, and eosinophils [24, 33].

In the present study, the effect of Der $\mathrm{p}$ on $\mathrm{T}$ cell expression of CysLT 1 was associated with an enhanced production of IL-4 and IL-10 in PBMC from allergic subjects, and both the enhanced $\mathrm{CysLT}_{1}$ expression and the enhanced responsiveness of T cells to $\mathrm{LTD}_{4}$ could be prevented when endogenous IL-4, but not IL-10, was neutralized. IL-4 and IL-10 were also able to significantly enhance mRNA and 

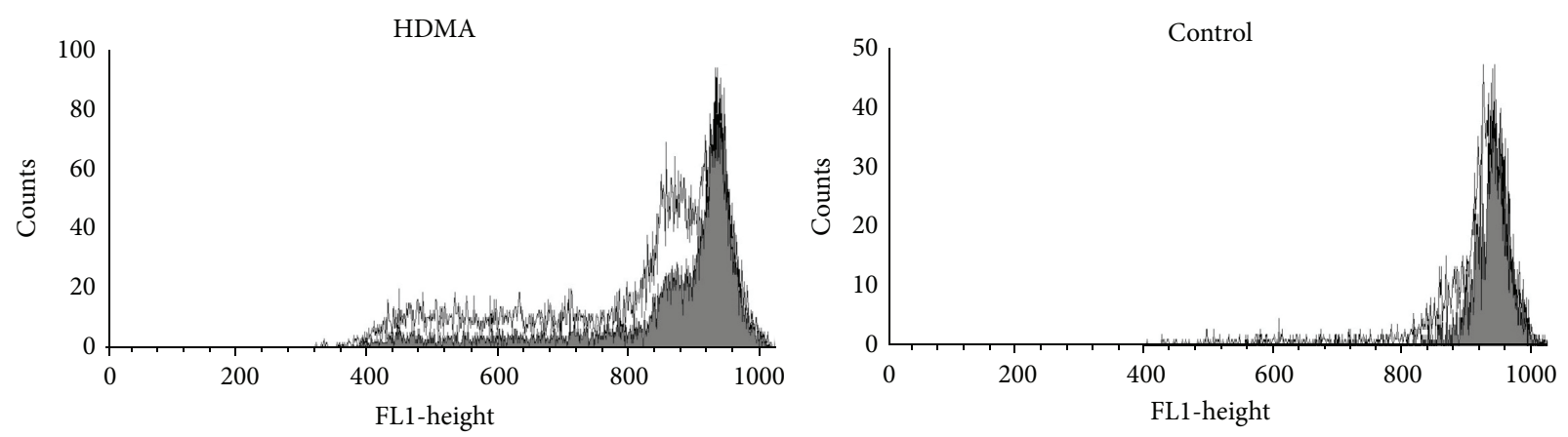

(a)

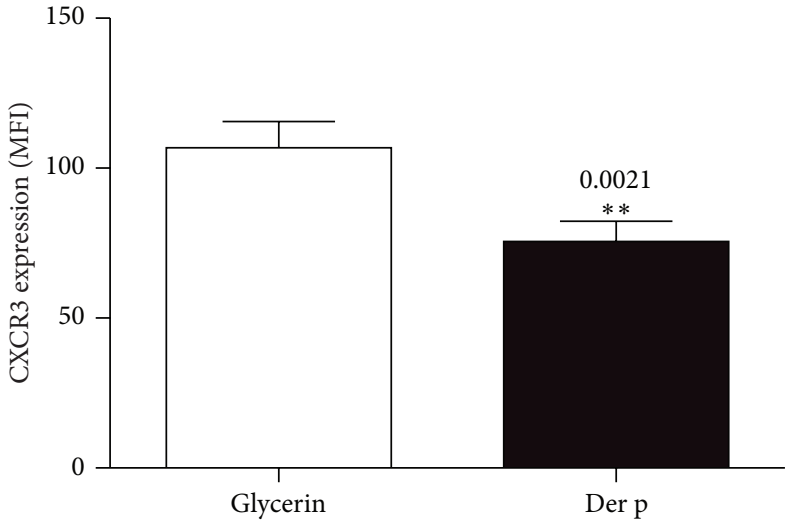

(b)

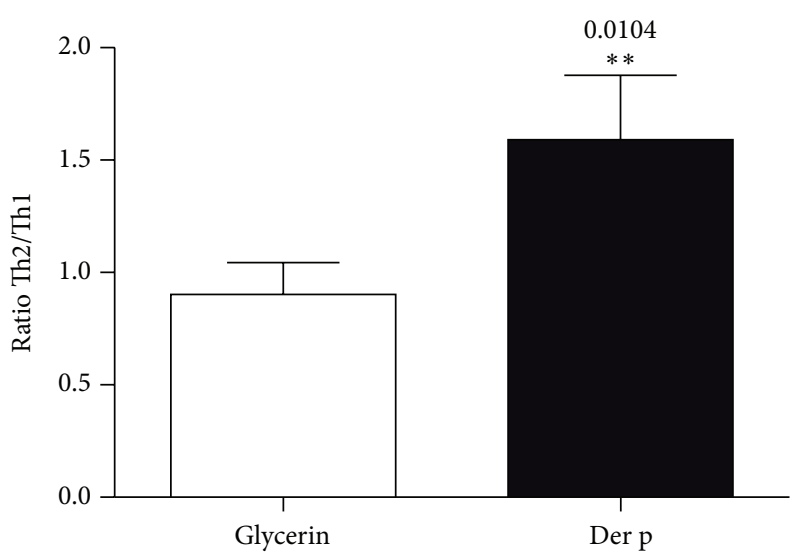

(d)

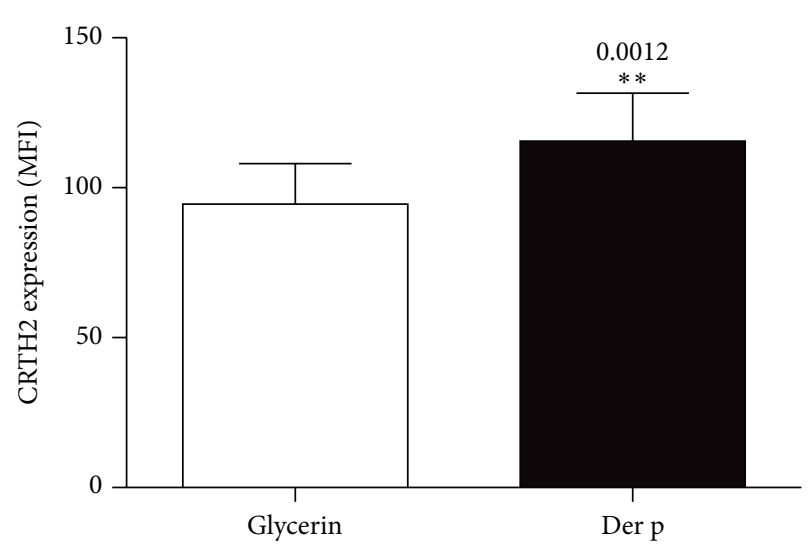

(c)

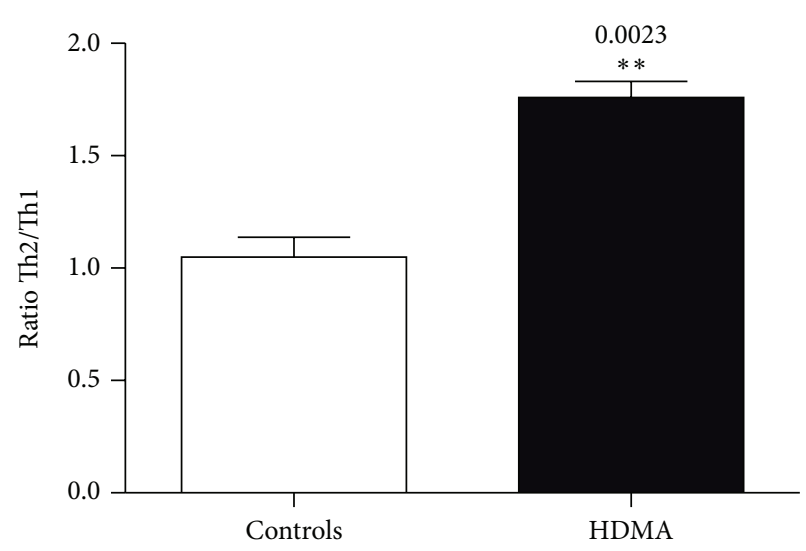

(e)

FIgURE 2: Flow-cytometric analysis of T cell proliferation and Th cell polarization. CFSE-labeled CD4 ${ }^{+}$T cells from HDM-allergic or HDMnonallergic individuals were cultured with Der p or glycerin as described in Section 2. T cell division was analyzed by flow cytometry and illustrated as a CFSE division profile (a). Dead cells were excluded based on their light scattering properties. Nondividing CD4 ${ }^{+} \mathrm{T}$ cells in the absence of allergen are shown as dark grey histograms. $\mathrm{CD} 4^{+} \mathrm{T}$ cells that have divided in response to Der p are shown in light grey histograms, based on CFSE dilution peaks. One representative experiment of three is illustrated. In vitro polarization of human Th1 and Th2 precursors following 11 days of culture with glycerin or Der $\mathrm{p}$ was determined by flow cytometry using Alexa-conjugated Abs for human CXCR3 (b) or CRTH2 (c), respectively. Data are expressed as geometric mean $( \pm$ SEM) fluorescence intensity $(\mathrm{MFI}) . P$ values are indicated. HDMA $=$ house dust mite-allergic donors. Th2/Th1 ratio of $\mathrm{CD}^{+} \mathrm{T}$ cells from HDM-allergic donors following 11 days of culture with glycerin or Der $\mathrm{p}$ (d), $n=6$; Th2/Th1 ratio of Der p-stimulated CD4 ${ }^{+} \mathrm{T}$ cells from nonallergic and HDM-allergic individuals (e), $n=6$ for controls; $n=10$ for HDMA. 


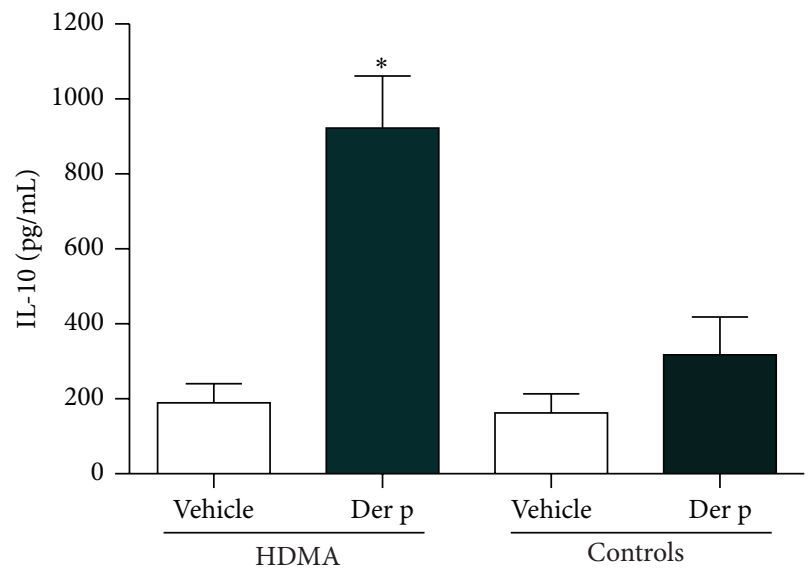

(a)

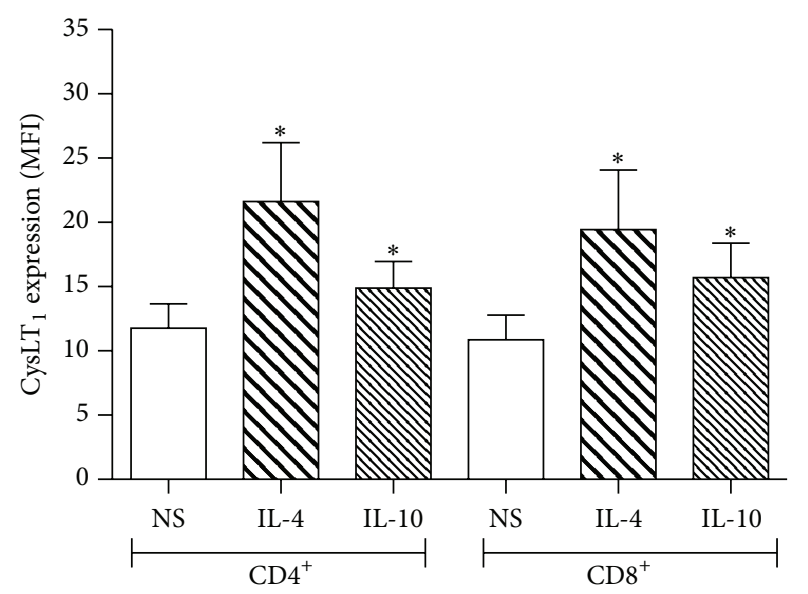

(c)

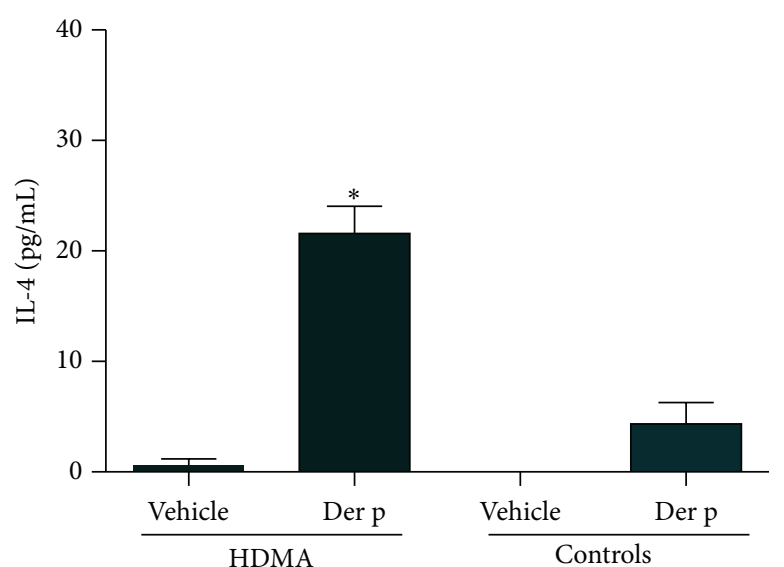

(b)

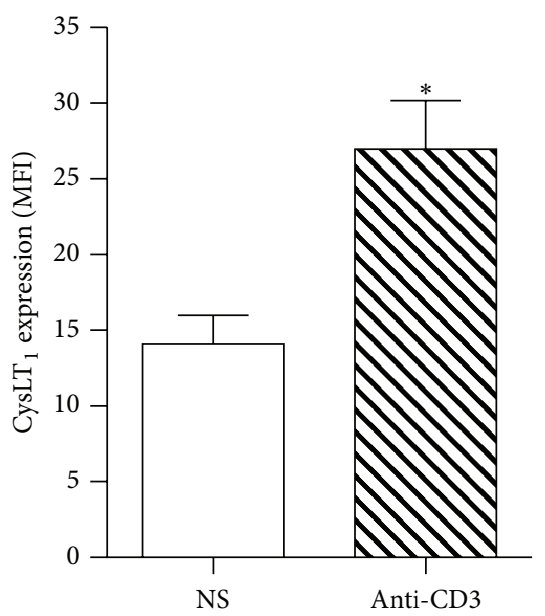

(d)
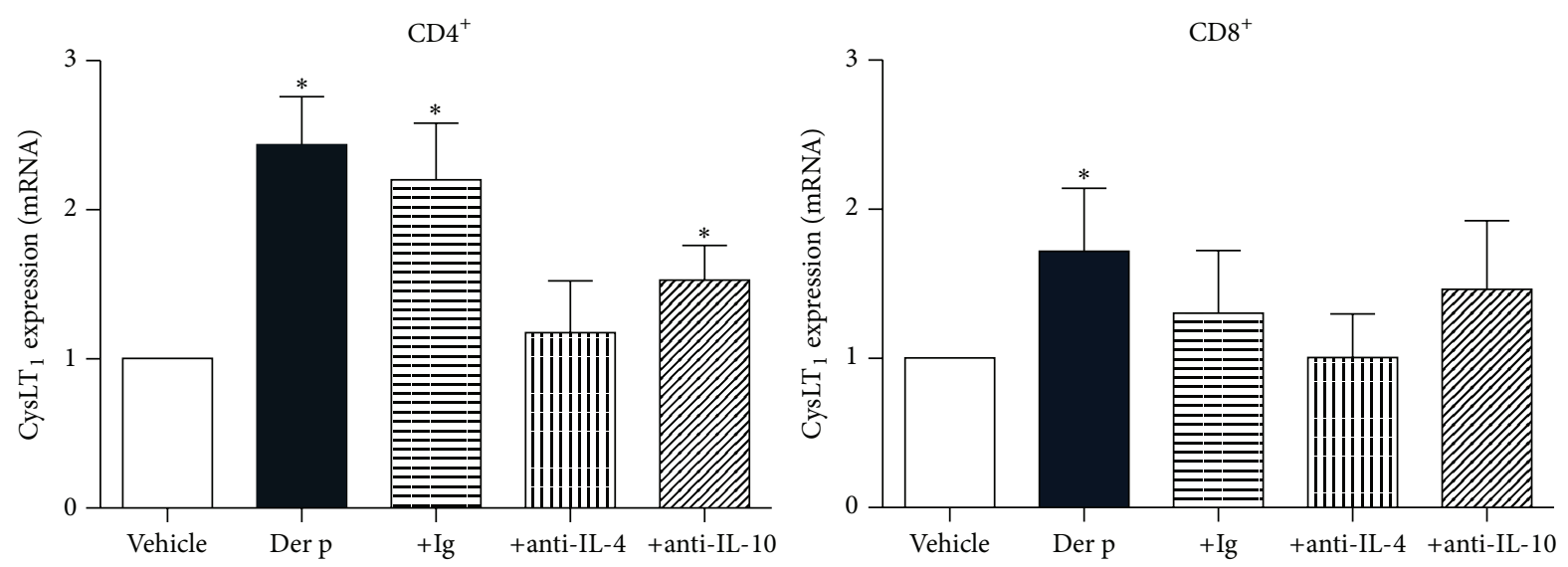

(e)

FIGURE 3: Cytokine production and effects in HDM-allergic and HDM-nonallergic individuals. PBMC from healthy controls and HDMA subjects were cultured for $72 \mathrm{~h}$ in the presence of glycerol vehicle or Der p before supernatants were collected for analysis. IL-4 (a) and IL-10 (b) production in cell-free culture supernatants were measured by ELISA. Results are expressed as means \pm SEM. $n=5$. CysLT $_{1}$ expression by T cells following stimulation with IL-4 $(40 \mathrm{ng} / \mathrm{mL})$ or IL-10 $(20 \mathrm{ng} / \mathrm{mL})$ (c) for $48 \mathrm{~h}$ or following TcR/CD3 stimulation (d) for $72 \mathrm{~h}$ was measured by flow cytometry. Data are expressed as geometric mean $( \pm$ SEM) fluorescence intensity (MFI). (e) PBMC from HDM-allergic (HDMA) individuals were cultured for $48 \mathrm{~h}$ or $72 \mathrm{~h}$ with Der $\mathrm{p}$ in the presence of neutralizing anti-IL- 4 or anti-IL-10 Abs or control IgG. CysLT $_{1}$ mRNA expression by $\mathrm{CD}^{+} \mathrm{T}$ cells and $\mathrm{CD}^{+} \mathrm{T}$ cells purified from PBMC at $48 \mathrm{~h}$ after stimulation was measured by real-time quantitative PCR analysis. Data are presented as fold $(\Delta \Delta \mathrm{Ct})$ increases over GAPDH mRNA \pm SEM for $n=5$ experiments; ${ }^{*} P<0.05$ with respect to the vehicle. 


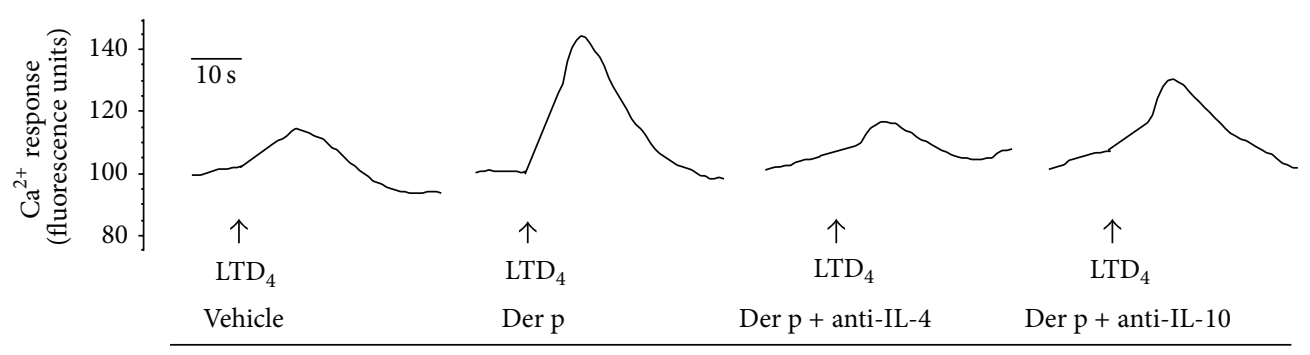

Pretreatment

(a)

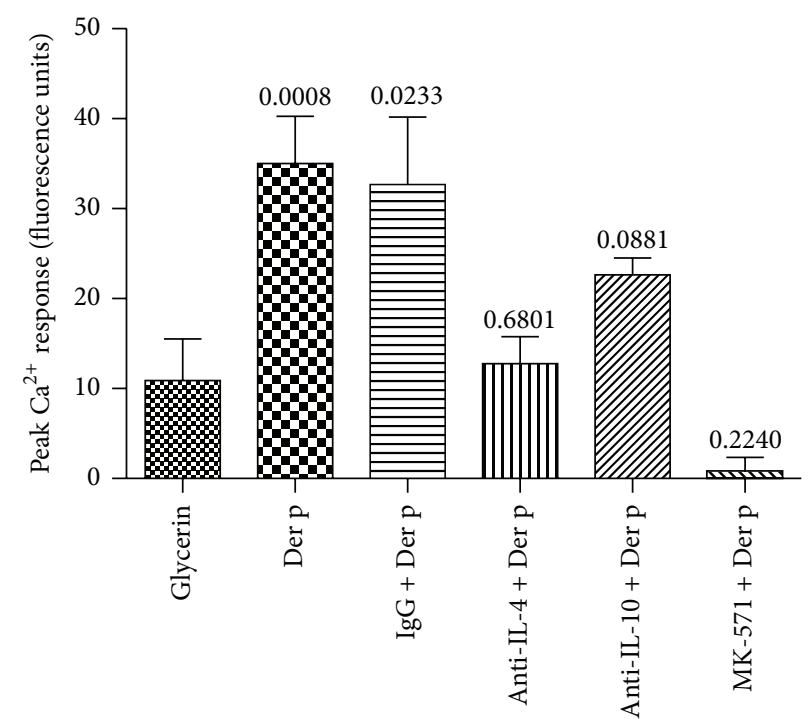

(b)

Figure 4: Functional analysis of increased CysLT $_{1}$ expression on $\mathrm{T}$ cells. The biological significance of the enhanced CysLT $\mathrm{T}_{1}$ receptor expression on $\mathrm{T}$ cells was assessed by measuring intracellular calcium flux in response to $\mathrm{LTD}_{4}$. PBMC from HDM-allergic (HDMA) individuals were exposed for $72 \mathrm{~h}$ to Der $\mathrm{p}$ in the presence or absence of neutralizing Abs to IL- 4 or IL-10 or of the CysLT receptor antagonist MK571. Cells were then labeled with anti-CD3 and anti-CD4 Ab and loaded with Fluo4-AM for the calcium mobilization assay on a FACSCalibur flow cytometer. (a) Raw data representative of 4 separate experiments. (b) Compiled data of peak calcium responses. $n=3 ; P$ values indicated above histograms, with respect to the vehicle.

protein levels of CysLT 1 in purified $\mathrm{T}$ cells. In contrast, $\mathrm{T}$ cells from non-HDM-allergic individuals appeared to be unable to respond to Der p suggesting that this effect would be antigen specific and dependent on prior sensitization. However, augmentation in $\mathrm{CysLT}_{1}$ expression could be induced in $\mathrm{T}$ cells from nonallergic donors through activation of the $\mathrm{T}$ cell receptor/CD3 complex or with the cytokines IL-4 and IL-10.

Previous studies have indicated that CysLT receptor expression could be altered by various stimuli in different cell types. Others and we have previously reported the expres-

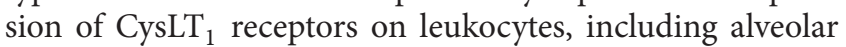
and monocyte-derived macrophages, as well as DC and B lymphocytes $[3,7,8,10,17]$. In particular, CysLT $_{1}$ expression levels were upregulated by IL-13 and IL- 4 in monocytes and macrophages and resulted in enhanced $\mathrm{Ca}^{2+}$ transients and chemotactic responses to $\mathrm{LTD}_{4}$ [17]. Whereas T lymphocytes were previously shown to display low surface expression of CysLT $_{1}$ and CysLT 2 , $\mathrm{T}$ cells activation through the $\mathrm{T}$ cell receptor (TcR) was shown to enhance the percentages of CysLT $_{1}$ and CysLT $_{2}$ positive cells [30]. In a murine model,
Prinz et al. [13] reported CysLT 1 upregulation after TcR activation of mouse $\mathrm{T}$ cells which was associated with enhanced $\mathrm{LTD}_{4}$-elicited calcium flux and migration toward $\mathrm{LTD}_{4}$. More recently, IL-4 was also shown to upregulate $\mathrm{CysLT}_{1}$ and CysLT $_{2}$ expression on $\mathrm{T}$ and $\mathrm{B}$ cells, whereas IFN- $\gamma$ was shown to induce CysLT 2 expression on monocytes and $\mathrm{T}$ and B lymphocytes [12]. IL-4 is a known activator of STAT6 [34]. The identification of a STAT6 response element in the CysLT 1 receptor promoter was proposed to be one of the mechanisms that mediate enhanced CysLT 1 expression following IL-4 stimulation [35]. Our observation that Der p induced CysLT expression in $\mathrm{T}$ cells could be partially dependent on this mechanism of transactivation of the CysLT ${ }_{1}$ promoter by STAT6.

The polarization of the immune response toward a Th2 or a Th1 profile can be mediated by APC following antigen presentation and interaction with $\mathrm{T}$ cells. In sensitized individuals, recruitment of Th2 cells and subsequent production of Th2-type cytokines like IL-4, IL-5, and IL-13 orchestrate the inflammatory response to inhaled aeroallergens. Our 
results showed that Der p induced $\mathrm{CD} 4^{+} \mathrm{T}$ cells to proliferate and favored $\mathrm{T}$ lymphocyte differentiation towards a Th2 phenotype in HDM-allergic donors. Hence, we observed that Der $\mathrm{p}$ treatment induced IL-4 production and increased the expression of CRTH2 (CD294), a marker for Th2 cells [32], while it reduced the expression of CXCR3 (CD183), a marker for Th1 cells [31]. In counterpart, $\mathrm{T}$ cells from healthy control donors did not proliferate in the presence of Der $\mathrm{p}$ and their Th1 and Th2 markers were not affected. These observations are in concordance with several studies demonstrating the promotion of Th2 responses by HDM allergens. Mite allergen-specific $\mathrm{T}$ cell clones from atopic donors exhibit a Th2 cytokine profile [36] and require IL-4 for their optimal growth [37]. Different studies have shown that DC from allergic patients exposed to the allergen Der $p$ 1 could promote Th 2 responses. In atopic patients, DC pulsed with HDM allergens produced a significant increase in cysLT production and showed a Th2-favoring phenotype with a Th2-skewed cytokine production from autologous $\mathrm{CD} 4^{+} \mathrm{T}$ cells [25]. Also Der $\mathrm{p} 1$ induced a rapid and higher production of proinflammatory cytokines TNF- $\alpha$, IL- $1 \beta$ and the type 2 cytokine IL-10 by DC from HDM-sensitive patients and that their purified T cells stimulated by autologous Der p 1-pulsed DC preferentially produced IL-4 rather than IFN- $\gamma[27,28]$. In another study, Der $\mathrm{p} 1$ was shown to bias human $\mathrm{T}$ cells towards a type 2 cytokine profile by inducing them to produce more IL-4 and less IFN- $\gamma$ [29]. DC from allergic patients exposed in vitro to Der $\mathrm{p} 1$ were shown to rapidly increase their TARC (CCL17) and MDC (CCL22) production, two type- 2 attracting chemokines known to be involved in the polarisation of the immune response [38]. DC from patients sensitive to Dermatophagoides react to Der p 1 (IL-6 and IL-10 production) differently from DC from healthy donors (IL-12 production), not only in vitro $[27,28]$, but also in vivo [39]. It has been reported that HDM extracts could also stimulate the production of IL-4 and IL-13 in mite-sensitive asthmatic basophils and activate IL-8 release in epithelial cells $[40,41]$. IL-10 and IL-4 production was shown to be induced by peripheral blood leukocytes from patients with asthma after exposure to the mite allergen $D$. farinae [42].

Our findings are also in concordance with recent work of Parmentier et al. which showed that human Th2 cells preferentially express CYSLTR1 mRNA after in vitro differentiation from naive precursors and selectively respond to cysLTs with calcium flux and chemotaxis [11].

Proteases, including serine and cysteine protease, have been considered critical factors in the cytokine expression modulated by mite allergens $[43,44]$. Der $\mathrm{p} 1$ protein, the major allergen from the mite Dermatophagoides pteronyssi$n u s$, is characterized by its cysteine protease activity. However, studies have demonstrated that cytokine production induced by mite extracts is associated with both proteaseindependent and protease-mediated mechanisms. Der $\mathrm{p} 1$ has been shown to induce the release of GM-CSF, IL-6, and IL-8 because of its proteolytic activity in bronchial epithelial cells $[45,46]$. The proteolytic activity of Der $\mathrm{p} 1$ has also been shown to favor human T cell production of more IL- 4 and less IFN- $\gamma$ [29]. In THP-1 cells, Dermatophagoides pteronyssinus strongly increased the release of MCP-1, IL-6, and IL-8 and these responses were not associated with serine and cysteine proteases [47]. In our study, we used the cysteine proteasespecific inhibitor E-64 alone and together with the serine protease inhibitor aprotinin during the incubation of PBMC with Der $\mathrm{p} 1$. We observed only partial diminutions in Der pinduced CysLT 1 mRNA expression and calcium mobilization in $\mathrm{CD}^{+}{ }^{+} \mathrm{T}$ cells with the combination of the two inhibitors (data not illustrated).

In conclusion, whereas CysLT receptor expression has been generally reported to be low in $\mathrm{T}$ cells, allergeninduced inflammation could activate $\mathrm{T}$ cells and enhance their expression of the receptors, thus making them more responsive to cysLTs present in the tissues. More precisely, our data suggest that, in allergen-sensitized individuals, exposure to allergen can enhance $\mathrm{T}$ cell expression of CysLT ${ }_{1}$. This, in turn, would induce enhanced $\mathrm{CD} 4^{+} \mathrm{T}$ cell responsiveness to cysLTs, T cell activation, and Th2 polarization. These findings identify a novel mechanism by which potent indoor allergens may activate immune cells to promote allergic inflammation.

\section{Abbreviations}

HDM: House dust mite

LT: Leukotriene

cysLT: Cysteinyl-leukotriene

CysLT: cysLT receptor

PBMC: Peripheral blood mononuclear cells

Th2: $\quad$ T helper 2

Der p: Dermatophagoides pteronyssinus.

\section{Conflict of Interests}

The authors declare that there is no conflict of interests regarding the publication of this paper.

\section{Acknowledgments}

The authors are grateful to the blood donors for their generosity. This work was supported by a grant to Jana Stankova and Marek Rola-Pleszczynski from the Canadian Institutes of Health Research. Jana Stankova and Marek Rola-Pleszczynski are members of the FRQS-funded Centre de Recherche du Centre Hospitalier Universitaire de Sherbrooke. Marek RolaPleszczynski was the recipient of a Canada Research Chair in Inflammation.

\section{References}

[1] R. A. Lewis, K. F. Austen, and R. J. Soberman, "Leukotrienes and other products of the 5-lipoxygenase pathway. Biochemistry and relation to pathobiology in human diseases," The New England Journal of Medicine, vol. 323, no. 10, pp. 645-655, 1990.

[2] C. Brink, S.-E. Dahlen, J. Drazen et al., "International Union of Pharmacology XXXVII. Nomenclature for leukotriene and lipoxin receptors," Pharmacological Reviews, vol. 55, no. 1, pp. 195-227, 2003.

[3] K. R. Lynch, G. P. O’Neill, Q. Liu et al., "Characterization of the human cysteinyl leukotriene CysLT1 receptor," Nature, vol. 399, no. 6738 , pp. 789-793, 1999. 
[4] H. M. Sarau, R. S. Ames, J. Chambers et al., "Identification, molecular cloning, expression, and characterization of a cysteinyl leukotriene receptor," Molecular Pharmacology, vol. 56, no. 3, pp. 657-663, 1999.

[5] C. E. Heise, B. F. O’Dowd, D. J. Figueroa et al., "Characterization of the human cysteinyl leukotriene 2 receptor," The Journal of Biological Chemistry, vol. 275, no. 39, pp. 30531-30536, 2000.

[6] Y. Kanaoka, A. Maekawa, and K. F. Austen, "Identification of GPR99 protein as a potential third cysteinyl leukotriene receptor with a preference for leukotriene E4 ligand," The Journal of Biological Chemistry, vol. 288, no. 16, pp. 10967-10972, 2013.

[7] D. J. Figueroa, R. M. Breyer, S. K. Defoe et al., "Expression of the cysteinyl leukotriene 1 receptor in normal human lung and peripheral blood leukocytes," The American Journal of Respiratory and Critical Care Medicine, vol. 163, no. 1, pp. 226233, 2001.

[8] J. Lamoureux, J. Stankova, and M. Rola-Pleszczynski, "Leukotriene $\mathrm{D}_{4}$ enhances immunoglobulin production in CD40activated human B lymphocytes," The Journal of Allergy and Clinical Immunology, vol. 117, no. 4, pp. 924-930, 2006.

[9] C. Lemiere, S. Pelissier, C. Tremblay et al., "Leukotrienes and isocyanate-induced asthma: a pilot study," Clinical and Experimental Allergy, vol. 34, no. 11, pp. 1684-1689, 2004.

[10] M. Thivierge, J. Stankova, and M. Rola-Pleszczynski, “Toll-like receptor agonists differentially regulate cysteinyl-leukotriene receptor 1 expression and function in human dendritic cells," The Journal of Allergy and Clinical Immunology, vol. 117, no. 5, pp. 1155-1162, 2006.

[11] C. N. Parmentier, E. Fuerst, J. McDonald et al., "Human $\mathrm{T}_{H} 2$ cells respond to cysteinyl leukotrienes through selective expression of cysteinyl leukotriene receptor 1," Journal of Allergy and Clinical Immunology, vol. 129, no. 4, pp. 1136-1142, 2012.

[12] S. B. Early, E. Barekzi, J. Negri, K. Hise, L. Borish, and J. W. Steinke, "Concordant modulation of cysteinyl leukotriene receptor expression by IL-4 and IFN-gamma on peripheral immune cells," The American Journal of Respiratory Cell and Molecular Biology, vol. 36, no. 6, pp. 715-720, 2007.

[13] I. Prinz, C. Gregoire, H. Mollenkopf et al., “The type 1 cysteinyl leukotriene receptor triggers calcium influx and chemotaxis in mouse $\alpha \beta$ - and $\gamma \delta$ effector T cells," Journal of Immunology, vol. 175, no. 2, pp. 713-719, 2005.

[14] Y. Amrani, P. E. Moore, R. Hoffman, S. A. Shore, and R. A. Panettieri Jr., "Interferon- $\gamma$ modulates cysteinyl leukotriene receptor-1 expression and function in human airway myocytes," American Journal of Respiratory and Critical Care Medicine, vol. 164, no. 11, pp. 2098-2101, 2001.

[15] K. Espinosa, Y. Bossé, J. Stankova, and M. Rola-Pleszczynski, "CysLT1 receptor upregulation by TGF- $\beta$ and IL-13 is associated with bronchial smooth muscle cell proliferation in response to $\mathrm{LTD}_{4}$," The Journal of Allergy and Clinical Immunology, vol. 111, no. 5, pp. 1032-1040, 2003.

[16] M. Thivierge, M. Doty, J. Johnson, J. Stankova, and M. RolaPleszczynski, "IL-5 up-regulates cysteinyl leukotriene 1 receptor expression in HL-60 cells differentiated into eosinophils," The Journal of Immunology, vol. 165, no. 9, pp. 5221-5226, 2000.

[17] M. Thivierge, J. Staňková, and M. Rola-Pleszczynski, "IL-13 and IL-4 up-regulate cysteinyl leukotriene 1 receptor expression in human monocytes and macrophages," The Journal of Immunology, vol. 167, no. 5, pp. 2855-2860, 2001.

[18] Y. Bossé, C. Thompson, S. McMahon, C. M. Dubois, J. Stankova, and M. Rola-Pleszczynski, "Leukotriene D4-induced, epithelial cell-derived transforming growth factor $\beta 1$ in human bronchial smooth muscle cell proliferation," Clinical and Experimental Allergy, vol. 38, no. 1, pp. 113-121, 2008.

[19] S. Poulin, C. Thompson, M. Thivierge et al., "Cysteinylleukotrienes induce vascular endothelial growth factor production in human monocytes and bronchial smooth muscle cells," Clinical and Experimental Allergy, vol. 41, no. 2, pp. 204-217, 2011.

[20] M. Thivierge, J. Stankova, and M. Rola-Pleszczynski, “Cysteinylleukotriene receptor type 1 expression and function is downregulated during monocyte-derived dendritic cell maturation with zymosan: involvement of IL-10 and prostaglandins," The Journal of Immunology, vol. 183, no. 10, pp. 6778-6787, 2009.

[21] C. Thompson, A. Cloutier, Y. Bossé et al., "CysLT1 receptor engagement induces activator protein-1- and NF- $\kappa \mathrm{B}$-dependent IL-8 expression," American Journal of Respiratory Cell and Molecular Biology, vol. 35, no. 6, pp. 697-704, 2006.

[22] W. W. Busse and L. J. Rosenwasser, "Mechanisms of asthma," Journal of Allergy and Clinical Immunology, vol. 111, no. 3, pp. S799-S804, 2003.

[23] D. J. Figueroa, L. Borish, D. Baramki, G. Philip, C. P. Austin, and J. F. Evans, "Expression of cysteinyl leukotriene synthetic and signalling proteins in inflammatory cells in active seasonal allergic rhinitis," Clinical and Experimental Allergy, vol. 33, no. 10, pp. 1380-1388, 2003.

[24] Y. Obase, T. Shimoda, S.-Y. Tomari et al., "Effects of pranlukast on chemical mediators in induced sputum on provocation tests in atopic and aspirin-intolerant asthmatic patients," Chest, vol. 121, no. 1, pp. 143-150, 2002.

[25] S. Saeki, H. Matsuse, Y. Kondo et al., "Effects of antiasthmatic agents on the functions of peripheral blood monocyte-derived dendritic cells from atopic patients," The Journal of Allergy and Clinical Immunology, vol. 114, no. 3, pp. 538-544, 2004.

[26] I. Machida, H. Matsuse, Y. Kondo et al., "Cysteinyl leukotrienes regulate dendritic cell functions in a murine model of asthma," The Journal of Immunology, vol. 172, no. 3, pp. 1833-1838, 2004.

[27] E. E. Comoy, J. Pestel, C. Duez et al., “The house dust mite allergen, Dermatophagoides pteronyssinus, promotes type 2 responses by modulating the balance between IL- 4 and IFN- $\gamma$," The Journal of Immunology, vol. 160, no. 5, pp. 2456-2462, 1998.

[28] H. Hammad, A.-S. Charbonnier, C. Duez et al., "Th2 polarization by Der p 1-pulsed monocyte-derived dendritic cells is due to the allergic status of the donors," Blood, vol. 98, no. 4, pp. 1135-1141, 2001.

[29] A. M. Ghaemmaghami, A. Robins, L. Gough, H. F. Sewell, and F. Shakib, "Human T cell subset commitment determined by the intrinsic property of antigen: the proteolytic activity of the major mite allergen Der $\mathrm{p} 1$ conditions $\mathrm{T}$ cells to produce more IL-4 and less IFN- $\gamma$," European Journal of Immunology, vol. 31, no. 4, pp. 1211-1216, 2001.

[30] F. Spinozzi, A. M. Russano, S. Piattoni et al., "Biological effects of montelukast, a cysteinyl-leukotriene receptor-antagonist, on T lymphocytes," Clinical and Experimental Allergy, vol. 34, no. 12, pp. 1876-1882, 2004.

[31] R. Bonecchi, G. Bianchi, P. P. Bordignon et al., "Differential expression of chemokine receptors and chemotactic responsiveness of type $1 \mathrm{~T}$ helper cells (Th1s) and Th2s," The Journal of Experimental Medicine, vol. 187, no. 1, pp. 129-134, 1998.

[32] K. Nagata, K. Tanaka, K. Ogawa et al., "Selective expression of a novel surface molecule by human Th2 cells in vivo," The Journal of Immunology, vol. 162, no. 3, pp. 1278-1286, 1999. 
[33] A. K. Behera, M. Kumar, H. Matsuse, R. F. Lockey, and S. S. Mohapatra, "Respiratory syncytial virus induces the expression of 5-lipoxygenase and endothelin-1 in bronchial epithelial cells," Biochemical and Biophysical Research Communications, vol. 251, no. 3, pp. 704-709, 1998.

[34] K. Takeda, T. Kishimoto, and S. Akira, "STAT6: its role in interleukin 4-mediated biological functions," Journal of Molecular Medicine, vol. 75, no. 5, pp. 317-326, 1997.

[35] G. Woszczek, R. Pawliczak, H.-Y. Qi et al., "Functional characterization of human cysteinyl leukotriene 1 receptor gene structure," The Journal of Immunology, vol. 175, no. 8, pp. 51525159, 2005.

[36] E. A. Wierenga, M. Snoek, J. D. Bos, H. M. Jansen, and M. L. Kapsenberg, "Comparison of diversity and function of house dust mite-specific T lymphocyte clones from atopic and nonatopic donors," European Journal of Immunology, vol. 20, no. 7, pp. 1519-1526, 1990.

[37] B. N. Michael and R. S. Kalish, "House dust mite-responsive human T cells require both interleukin 2 (IL2) and interleukin 4 for optimal proliferation, whereas IL2 alone is sufficient for proliferation of tetanus toxoid-responsive T cells," Cellular Immunology, vol. 158, no. 1, pp. 105-115, 1994.

[38] H. Hammad, H. H. Smits, C. Ratajczak et al., "Monocytederived dendritic cells exposed to Der $\mathrm{p} 1$ allergen enhance the recruitment of Th2 cells: major involvement of the chemokines TARC/CCL17 and MDC/CCL22," European Cytokine Network, vol. 14, no. 4, pp. 219-228, 2003.

[39] H. Hammad, B. N. Lambrecht, P. Pochard et al., "Monocytederived dendritic cells induce a house dust mite-specific Th2 allergic inflammation in the lung of humanized SCID mice: involvement of CCR7," The Journal of Immunology, vol. 169, no. 3, pp. 1524-1534, 2002.

[40] Y. Shimizu, M. Shichijo, K. Hiramatsu, M. Takeuchi, H. Nagai, and K. Takagi, "Mite antigen-induced IL-4 and IL-13 production by basophils derived from atopic asthma patients," Clinical and Experimental Allergy, vol. 28, no. 4, pp. 497-503, 1998.

[41] C. K. Wong, M. L. Y. Li, C. B. Wang, W. K. Ip, Y. P. Tian, and C. W. K. Lam, "House dust mite allergen Der p 1 elevates the release of inflammatory cytokines and expression of adhesion molecules in co-culture of human eosinophils and bronchial epithelial cells," International Immunology, vol. 18, no. 8, pp. 1327-1335, 2006.

[42] T. Noma, Y. Sugawara, N. Ogawa, T. Saeki, K. Yamaguchi, and Y. Kawano, "Dermatophagoides-induced interleukin-10 production by peripheral blood lymphocytes from patients with asthma in remission," Pediatric Allergy and Immunology, vol. 15, no. 5, pp. 459-468, 2004.

[43] C. King, S. Brennan, P. J. Thompson, and G. A. Stewart, "Dust mite proteolytic allergens induce cytokine release from cultured airway epithelium," Journal of Immunology, vol. 161, no. 7, pp. 3645-3651, 1998.

[44] G. Sun, M. A. Stacey, M. Schmidt, L. Mori, and S. Mattoli, "Interaction of mite allergens Der $\mathrm{p} 3$ and Der $\mathrm{p} 9$ with proteaseactivated receptor-2 expressed by lung epithelial cells," The Journal of Immunology, vol. 167, no. 2, pp. 1014-1021, 2001.

[45] J. F. C. Tomee, R. van Weissenbruch, J. G. R. de Monchy, and H. F. Kauffman, "Interactions between inhalant allergen extracts and airway epithelial cells: effect on cytokine production and cell detachment," The Journal of Allergy and Clinical Immunology, vol. 102, no. 1, pp. 75-85, 1998.

[46] H. F. Kauffman, M. Tamm, J. A. B. Timmerman, and P. Borger, "House dust mite major allergens Der p 1 and Der p 5 activate human airway-derived epithelial cells by protease-dependent and protease-independent mechanisms," Clinical and Molecular Allergy, vol. 4, article 5, 2006.

[47] J.-S. Lee, I. S. Kim, J.-S. Ryu, and C.-Y. Yun, "House dust mite, Dermatophagoides pteronissinus increases expression of MCP-1, IL-6, and IL-8 in human monocytic THP-1 cells," Cytokine, vol. 42 , no. 3, pp. 365-371, 2008. 


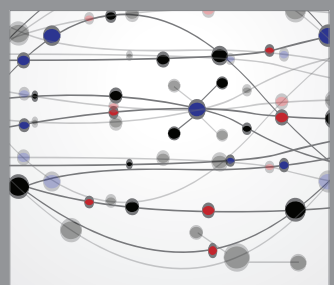

The Scientific World Journal
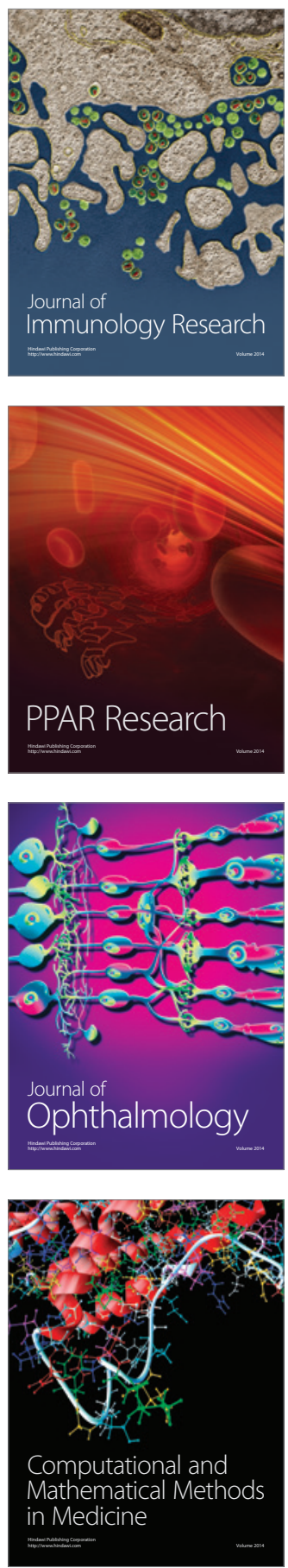

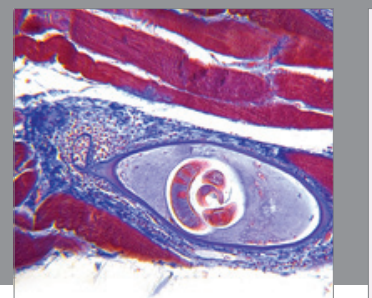

Gastroenterology

Research and Practice
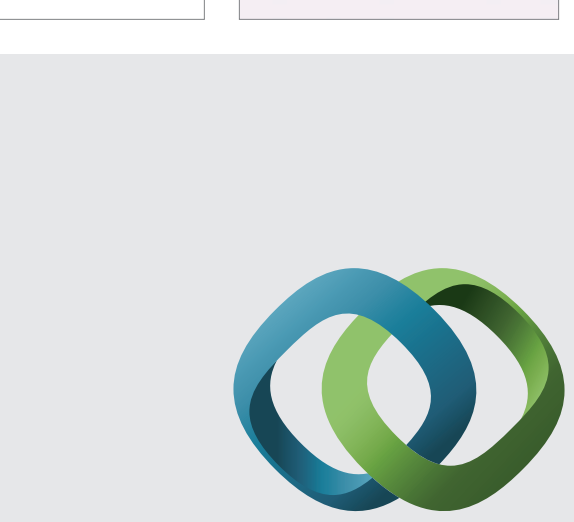

\section{Hindawi}

Submit your manuscripts at

http://www.hindawi.com
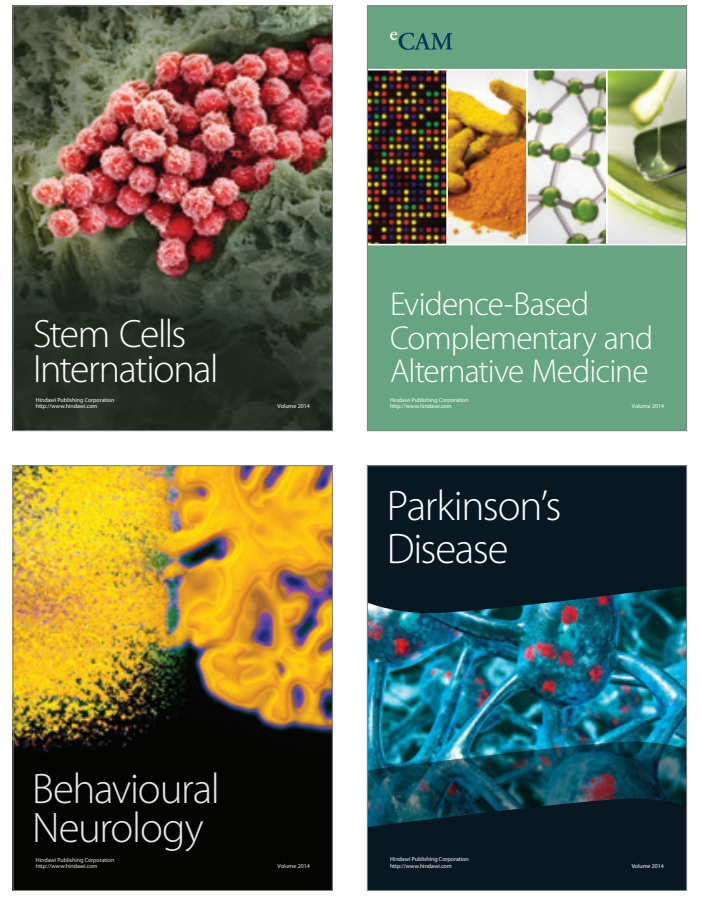
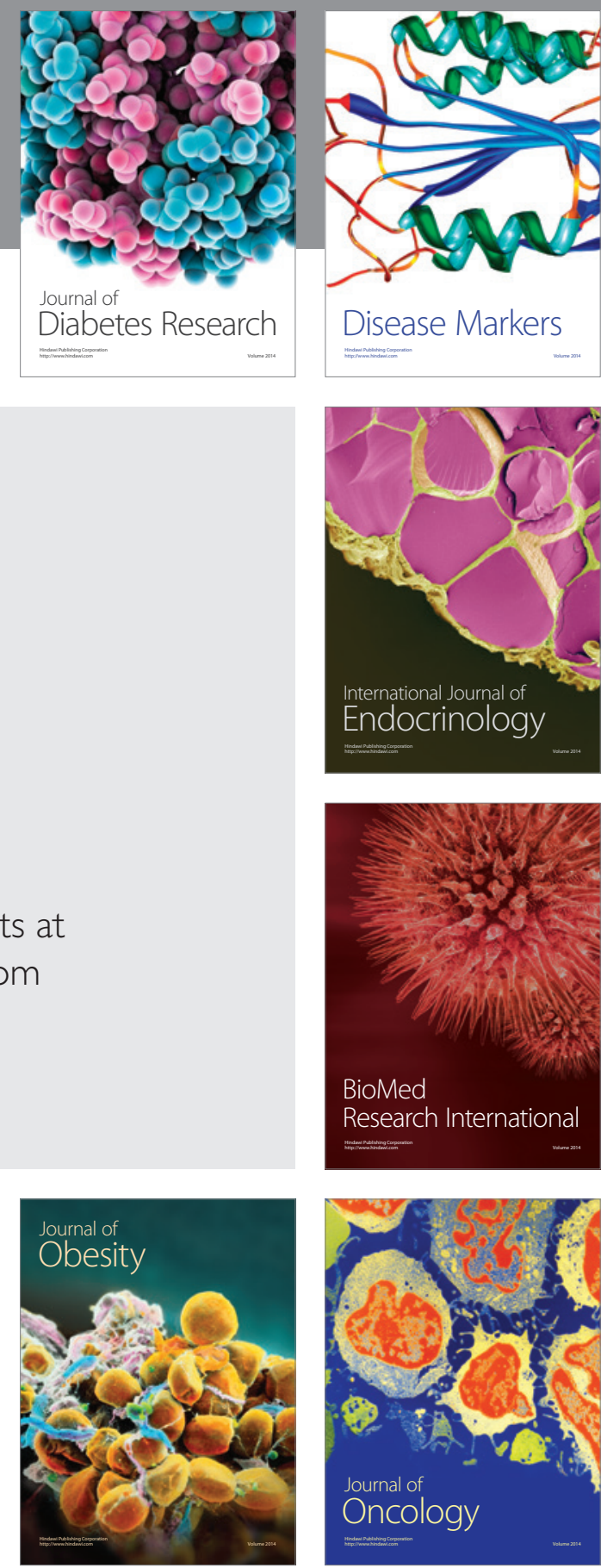

Disease Markers
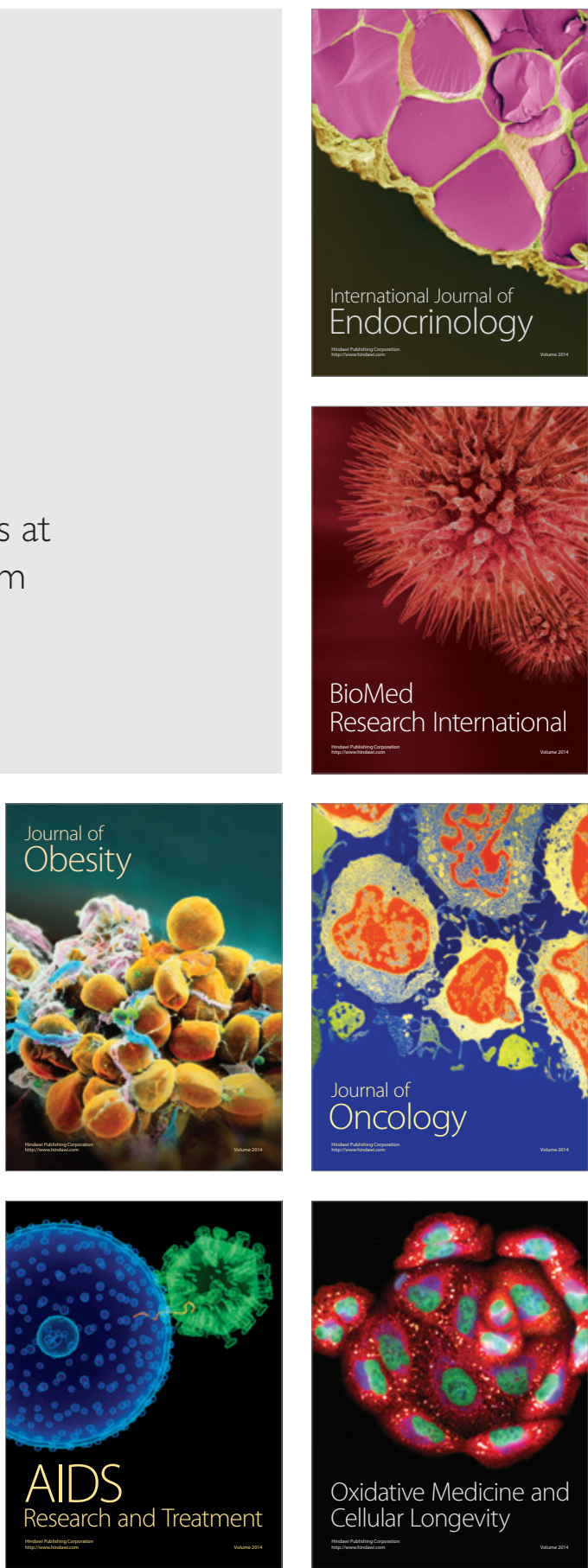